FOREST POLICIES AND SOCIAL CHANGE IN ENGLAND 


\title{
WORLD FORESTS
}

\author{
Series Editors
}

\section{MATTI PALO}

PhD, Independent Scientist, Finland, Affiliated Professor CATIE, Costa Rica

\section{JUSSI UUSIVUORI}

Finnish Forest Research Institute METLA, Finland

\section{Advisory Board}

Janaki Alavalapati, University of Florida, USA

Joseph Buongiorno, University of Wisconsin, USA

Jose Campos, CATIE, Costa Rica

Sashi Kant, University of Toronto, Canada

Maxim Lobovikov, FAO/Forestry Department, Rome

Misa Masuda, University of Tsukuba

Roger Sedjo, Resources for the Future, USA

Brent Sohngen, Ohio State University, USA

Yaoqi Zhang, Auburn University, USA

\section{World Forests Description}

As forests stay high on the global political agenda, and forest-related industries diversify, cutting edge research into the issues facing forests has become more and more transdisciplinary. With this is mind, Springer's World Forests series has been established to provide a key forum for research-based syntheses of globally relevant issues on the interrelations between forests, society and the environment.

The series is intended for a wide range of readers including national and international entities concerned with forest, environmental and related policy issues; advanced students and researchers; business professionals, non-governmental organizations and the environmental and economic media.

Volumes published in the series will include both multidisciplinary studies with a broad range of coverage, as well as more focused in-depth analyses of a particular issue in the forest and related sectors. Themes range from globalization processes and international policies to comparative analyses of regions and countries. 


\section{Forest Policies and Social Change in England}

SYLVIE NAIL

University of Paris III, Sorbonne Nouvelle, France

量 Springer 
Dr. Sylvie Nail

University of Paris III

Sorbonne Nouvelle

France

ISBN 978-1-4020-8364-8

e-ISBN 978-1-4020-8365-5

Library of Congress Control Number: 2008925104

(C) 2008 Springer Science + Business Media B.V.

No part of this work may be reproduced, stored in a retrieval system, or transmitted in any form or by any means, electronic, mechanical, photocopying, microfilming, recording or otherwise, without written permission from the Publisher, with the exception of any material supplied specifically for the purpose of being entered and executed on a computer system, for exclusive use by the purchaser of the work.

Cover illustration: New social uses for the woods. Photograph by Sylvie Nail.

Printed on acid-free paper

$98776 \begin{array}{llllll}9 & 8 & 3 & 2 & 1\end{array}$

springer.com 
In memory of Pam Jackson, the dearest of friends, always with me. 


\section{Acknowledgements}

Over the past few years, during the preparation of this book, I have been very lucky to meet many wonderful people involved in forestry, all of whom are dedicated to trees but more than anything else to people. In particular, I would like to thank all my interviewees, whether members of the general public, members of charitable organisations or of institutions like the Forestry Commission and the Community Forests. My gratitude goes especially to Paul Hill-Tout, Director of the Forestry Commission England, and to the Mersey Forest Team - especially Paul Nolan, its director, Lee Dudley, Jo Sayers and Dave Perry - who gave freely of their time for interviews, who were ever helpful and provided numerous illustrations.

I am also grateful to Eleanor Harland, librarian at the Forestry Commission at Alice Holt Research Station for her help and patience, and to Claudie Petit at the Laboratoire d'anthropologie urbaine (LAU) of the Centre national de la recherche scientifique (CNRS) in Paris, who made sure I received the documents I needed. I am greatly indebted to the LAU for its support which made many field trips possible in all seasons.

Many thanks to all my correspondents who gave me permission to reproduce their photographs. For documents with Crown copyright, a PSI licence has been obtained (number C2007002067).

At Springer, I would like to acknowledge the encouragement and help of Catherine Cotton and Ria Kanters, as well as the perceptive comments of Jussi Uusivuori and Matti Palo.

Special thanks are due to my friend Janet Rossiter, not only on account of her hospitality and of her constant endeavours to help me in my fieldwork by providing numerous contacts, but also for being brave enough to take on the proofreading of the book. Sarah Pickard was kind enough to check the last version of the manuscript. The mistakes that remain are mine, of course.

If the protracted work involved in research and publication tests lifelong friendships, it comes with the added bonus of new acquaintances, some of which turn into friendships. Cecil Konijnendijk and Mark Johnston are two very special people I was lucky to meet during this work, and I want to thank them for their support, comments and enthusiasm. 
I am especially indebted to Jose Luis, my husband, whose patience and listening capacities I tested to the utmost, and in whom I always found a source of support and of relevant advice. He and Théo have had to live with this book, and they deserve my heartfelt thanks for this. 


\section{Contents}

Acknowledgements ............................. vii

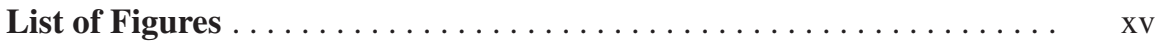

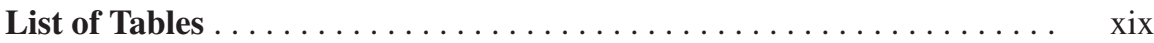

Introduction. . . . . . . . . . . . . . . . . . . . . . . . . . . .

1 Preliminary Chapter: Woodlands as Landscapes of Power ........ 7

1.1 British Woodlands, from Nature to Culture . . . . . . . . . . . . 7

1.1.1 Natural Woodland ...................... 7

1.1.2 The Beginnings of Cultivation ................ 9

1.2 Woodlands as Spaces of Exclusion .................. 11

1.2.1 The Forest Law . . . . . . . . . . . . . . . . . . . . 11

1.2.2 Hunting as an Aristocratic Privilege .............. 14

1.2.3 Reactions and Controversy .................. 15

1.3 The Economic Balance Between Agriculture and Forestry ...... 19

1.3.1 Woodlands as Residual Land Use.................. 19

1.3.2 The Uses of Wood and Timber . . . . . . . . . . . . . . . 21

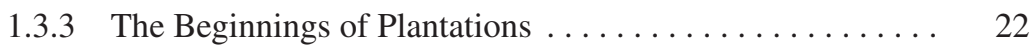

1.4 Wooden Walls and Hearts of Oak ................... 25

1.4.1 Political Identity ........................ 25

1.4.2 The Oak and the Navy .................... 27

1.4.3 Hardwoods and Social Status .................. 29

1.4.4 The Aesthetics of Tree-Planting ............... 32

\section{Part I The Institutionalisation of Forestry}

2 New Relationships with the Woodland. . . . . . . . . . . . . . 41

2.1 Agriculture in Crisis . . . . . . . . . . . . . . . . . 42

2.1.1 The End of the Landed Aristocracy ............... 42

2.1.2 Changing Needs in Woodland Products ............. 42

2.2 The Emergence of Scientific Forestry . . . . . . . . . . . . . 43 
2.2.1 The Disappearance of Amateurism............. 43

2.2.2 Towards a National Forest Policy . . . . . . . . . . . . . 44

2.3 Urbanisation and the Rural Idyll . . . . . . . . . . . . . . . . 45

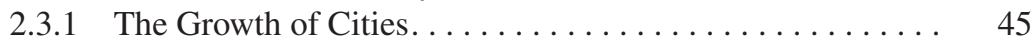

2.3.2 'Urban Hells' Versus Forest Heritage . . . . . . . . . . . 46

2.4 Woodland and Leisure for the Working-Class. . . . . . . . . . . . . 47

2.4.1 The Public Park Movement. . . . . . . . . . . . . . . . 47

2.4.2 Woodlands for Recreation..................... 49

3 The Productivist Dream and Its Aftermath. . . . . . . . . . . 53

3.1 The Traumatic Context of World War I. . . . . . . . . . . . . . 54

3.1 .1 The Acland Committee .................. 54

3.1.2 The Forestry Commission at Its Beginnings . . . . . . . . 55

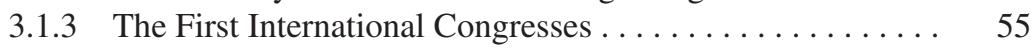

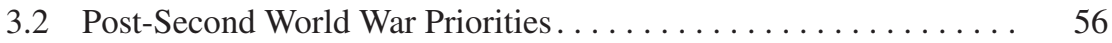

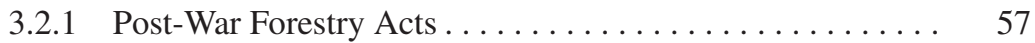

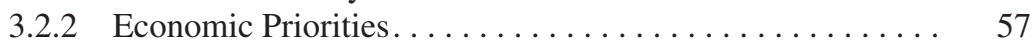

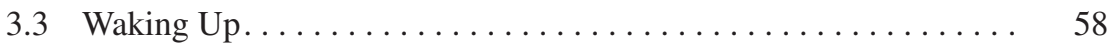

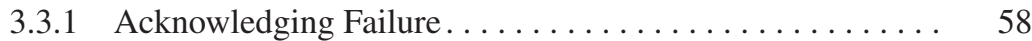

3.3 .2 Structural Changes . . . . . . . . . . . . . . . . 59

3.4 New Labour and the England Forestry Strategy . . . . . . . . . . . . . 60

3.4.1 Changing the Emphasis of Forestry . . . . . . . . . . 60

3.4.2 Devolution and Decentralisation............... 62

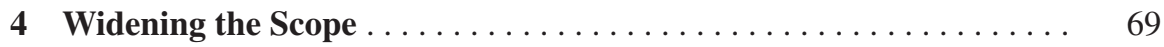

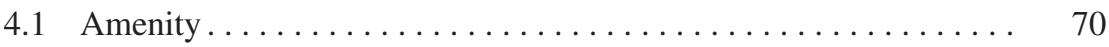

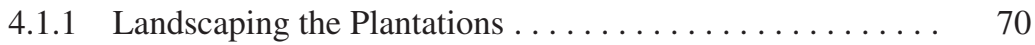

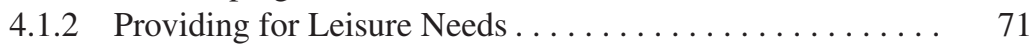

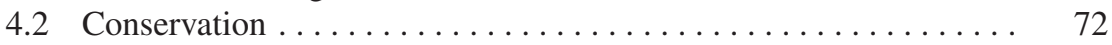

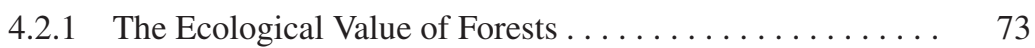

4.2.2 Protecting Ancient Woodlands . . . . . . . . . . . . . 74

4.3 Sustainability: A New Preoccupation in Forestry . . . . . . . . . . . 75

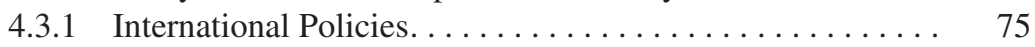

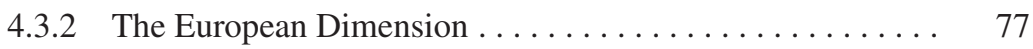

4.3.3 Sustainability in British Forests . . . . . . . . . . . . . . . 79

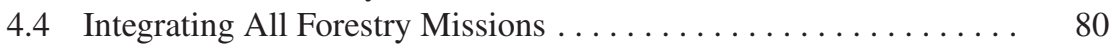

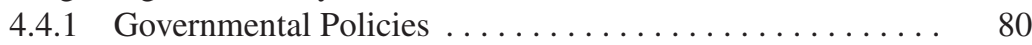

4.4.2 From the Global to the Local . . . . . . . . . . . 81

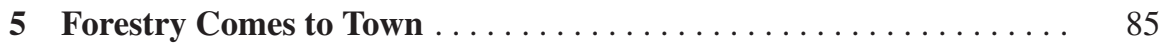

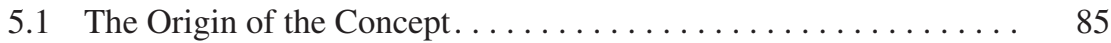

5.1 .1 Genesis and Definitions $\ldots \ldots \ldots \ldots \ldots \ldots \ldots \ldots \ldots$ 
5.1 .2 Coming of Age $\ldots \ldots \ldots \ldots \ldots \ldots \ldots \ldots \ldots \ldots$

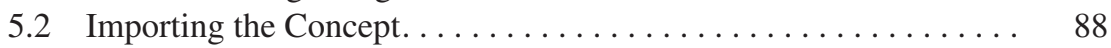

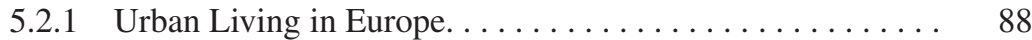

5.2.2 Research and Education .................... 89

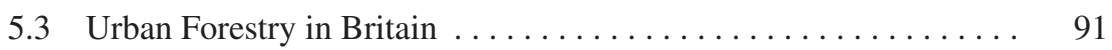

5.3 .1 Building Up a Toolkit . . . . . . . . . . . . . . . 91

5.3.2 From Resistance to Acceptance ................ 93

5.4 Governmental Involvement . . . . . . . . . . . . . . . . . . . 95

5.4 .1 Raising Awareness ... . . . . . . . . . . . . . . . . 95

5.4 .2 Local Government. . . . . . . . . . . . . . . . . . 96

5.4.3 The Creation of the Community Forests. . . . . . . . . . 98

\section{Part II Multi-Purpose Forestry: Another Name for Utopia?}

\section{The Economy of Postproductivist Forestry,}

The Impossible Challenge? . . . . . . . . . . . . . . . . . . . . . . . . 107

6.1 The Meanings of 'Profitability' . . . . . . . . . . . . . . . . . . . . . 109

6.1.1 Market Benefits.............................. 109

6.1.2 Non-market Benefits . . . . . . . . . . . . . . . . . 110

6.1 .3 New Mechanisms ..................... 112

6.2 New Outlets for Forest Products . . . . . . . . . . . . . . . . . . 114

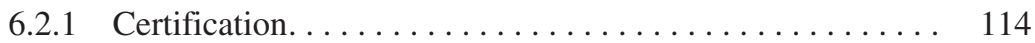

6.2 .2 Niche Markets. . . . . . . . . . . . . . . . . . . . . . . 115

6.3 The Markets of Recreation and Tourism. . . . . . . . . . . . . . . 119

6.3.1 The 'Leisure Explosion' . . . . . . . . . . . . . . . . . 120

6.3.2 Woodland and Tourism ................... 122

7 Phoenix Reborn: The Role of Forestry in Regeneration . . . . . . . . . . 129

7.1 Rural Regeneration . . . . . . . . . . . . . . . . . . . . . 130

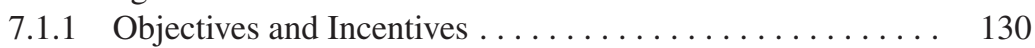

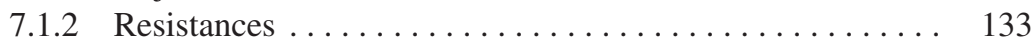

7.1 .3 Assessment .......................... 134

7.2 Industrial and Urban Regeneration . . . . . . . . . . . . . . 136

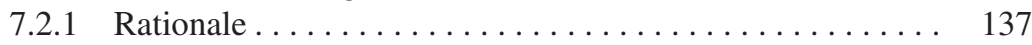

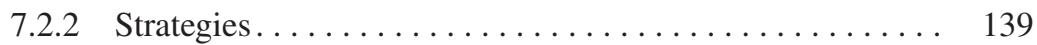

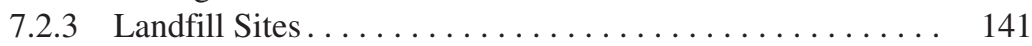

7.2.4 Mines and Industrial Sites. . . . . . . . . . . . . . 145

7.2 .5 The Case of the National Forest . . . . . . . . . . . . . . . 146

7.2 .6 Assessment ........................ 150

8 The Contribution of Woodlands to the Environment . . . . . . . . . . 157

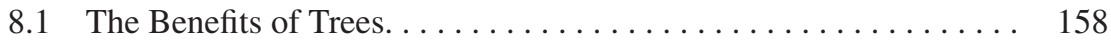

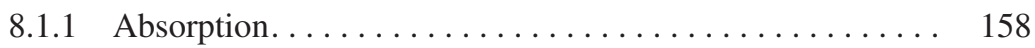




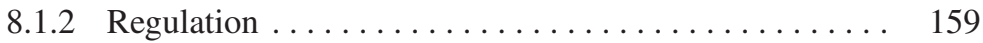

8.1 .3 Protection............................ 159

8.2 The 'Field of Dreams' ......................... 160

8.2.1 Trendy Trees and the Corporate Image . . . . . . . . 160

8.2.2 Tree Planting Versus Climate Change: Myths and Realities.......................... 162

8.2.3 The Limits of 'Green Power'. . . . . . . . . . . . . . . . . . . 164

8.2.4 Caring and Choosing ..................... 166

8.3 Tree Planting and Environmental Law .............. 168

8.3.1 Complying with Regulations and Expectations........ 168

8.3.2 Has the Bubble Burst? . . . . . . . . . . . . . . . . . . . . . 169

9 Social Forestry and the Health and Education Agenda ......... 175

9.1 The Birth of Social Forestry . . . . . . . . . . . . . . . 175

9.1 .1 Forest Research ......................... 176

9.1.2 The Social Research Unit. . . . . . . . . . . . . . . . . . . 176

9.2 Health and the Natural World ................... 177

9.2.1 Bidding Farewell to the Enlightenment . . . . . . . . . 177

9.2.2 The Thrust of Environmental Psychology .......... 178

9.2.3 Lifestyle Diseases and Green Therapies .......... 183

9.2.4 Implementing a New Conception of Health ........ 186

9.3 Education, a Newly-Born Target. . . . . . . . . . . . . . . . . . 190

9.3.1 Woodland as a Tool for Content-Learning. . . . . . . . . 190

9.3.2 School Grounds, Grounds for Growth . . . . . . . . . . 192

9.3.3 Sowing the Seeds of Citizenship . . . . . . . . . . . . . . . . 194

9.3.4 Bodies in the Woods ........................ 196

9.3.5 Assessment. .......................... 198

\section{Part III The Tree-Led Solution to Empowerment}

10 Forestry Paradigms and Resource Provision ............... 205

10.1 Questioning the Expert Paradigm ................. 206

10.1.1 Quantitative and Qualitative Valuation .......... 206

10.1.2 Challenging the 'Landscape Value' Approach ....... 207

10.1.3 Translating Values into Policies................ 208

10.2 Fresh Approaches to Environmental Valuation............ 211

10.2.1 Bridging the Gap ..................... 211

10.2.2 Multiple Value Forestry ................. 212

10.2.3 Reconciling Aesthetic and Biodiversity Values:

Towards a New Paradigm. . . . . . . . . . . . . . . . 214

10.3 The Key Issue of Access . . . . . . . . . . . . . . . . . . . . 216

10.3.1 Research into Needs.................... 216

10.3.2 Measures to Facilitate Access and Diversify Supply... . 219

10.3.3 Provision of Access Versus Land Use Structure ..... . 222

10.3.4 Access as the Best Enemy of the Woodlands ....... 225 
11 Woodland Participation and Community Building ......... 231

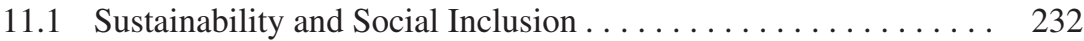

11.1.1 The Agenda ........................ 232

11.1.2 Building Up the Toolbox for Implementing and Assessing Participation ............... 234

11.2 From No Man's Lands to Thriving Communities . . . . . . . . . . . 241

11.2.1 Desperately Seeking Stakeholders. . . . . . . . . . . 241

11.2.2 Looking Outside the Box to Build Social Capital . . . . . 246

11.3 Ladders of Participation and Scales of Interest . . . . . . . . . 252

11.3.1 Love-Hate Relationship . . . . . . . . . . . . . . . 253

11.3.2 Woodlands as a Minority Interest . . . . . . . . 258

11.3.3 The Wider Picture: Community Development, Empowerment and Social Forestry ........... 261

12 Grafting the Past onto the Present: The Heritage of Woodlands

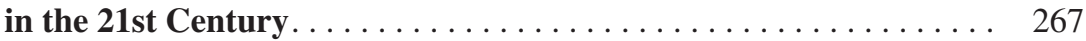

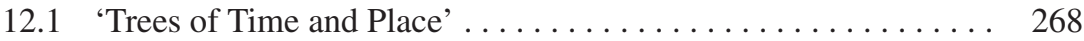

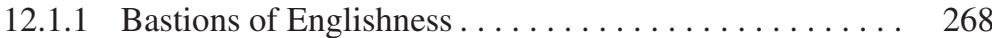

12.1.2 Perpetuating Practices ................. 272

12.1.3 Sylvan Myths, Religious and Pagan Landscapes. . . . . . 277

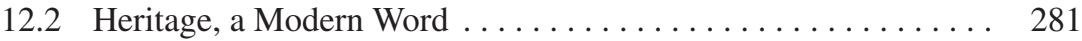

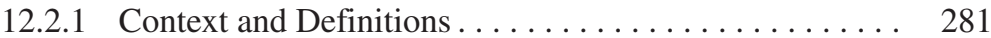

12.2.2 Policies and Incentives. . . . . . . . . . . . . . . . . 284

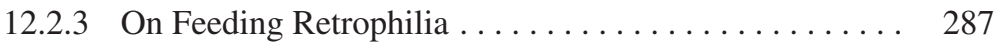

Concluding Remarks: Rebranding England Through

Consensual Woodlands? . . . . . . . . . . . . . . . . . . . . . . . . . . 293

Bibliography . . . . . . . . . . . . . . . . . . . . . . . . . . . . . 299

Chronology ............................... 317

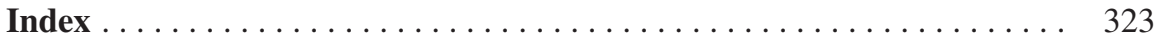




\section{List of Figures}

1.1 As many species of trees, willow coppices, sending up shoots from the stump, which can be cut down at regular intervals to be put to all sorts of domestic uses (Photo Sylvie Nail) . . . . . . . .

1.2 Anonymous woodcut engraving, c.1830, showing crowned King Charles II amidst the foliage of the Boscobel Oak: a variation on the theme of political symbology in relation to oak trees (From document SVII.113g, copyright William Salt Library, Stafford) . . . . 26

1.3 Anniversary Wood is part of Tunnel Woods (Derbyshire), a 34-hectare new wood planted as part of the National Forest with native tree species, with the contribution of the RSA (Photo courtesy of the RSA)

2.1 Birkenhead Park, Wirral. Designed by Joseph Paxton in 1844, it was opened to the public in 1847. It was the first municipal public park created by a local authority on public funds (Photo courtesy of the Wirral Council) . . . . . . . . . . . . .

3.1 The new structure of the Forestry Commission following devolution (From Forestry Commission 2004b: p. 63) . . . . . . . . . . . .

3.2 The spectacular growth of plantations over 130 years (From Area by planting year class. Forestry Commission. 2003b: 21 . .

5.1 Ironbridge Gorge (Telford), the birth place of the Industrial Revolution. Benthall Edge, in the background, is an ancient natural woodland in which a coppice regime has recently been reintroduced for habitat and access (Photo courtesy of Alan Simson). .

5.2 Publicising the Forest of London: Richard Branson, the famous entrepreneur, poses for the press after climbing the tallest tree in central London (Photo courtesy of Mark Johnston) 
5.3 Map of the 12 English Community Forests (Map courtesy of the Tees Community Forest $) \ldots \ldots \ldots \ldots \ldots \ldots \ldots$

6.1 Creating a sense of ownership while using the timber resource: magnets, kitchen spatulas and bread boards made from cherry, sycamore and beech trees from the Mersey Forest (Photo courtesy of the Mersey Forest) . . . . . . . . . . . . .

6.2 Bags of kindling wood and small firelogs for sale at a petrol station (Photo courtesy of Mark Johnston) . . . . . . . . . . .

7.1 Willow plantation for short rotation coppice on a Yorkshire farm (Photo courtesy of Forest Research) . . . . . .

7.2 Historical continuity in Frodsham (Cheshire): a recently planted woodland, adjacent to Hobshaywood, an ancient woodland (Photo Sylvie Nail) . . . . . . . . . . . . . . . . .

7.3 From rubbish tip to community woodland:

Bisdston Moss in 1996 before regeneration

(Photo courtesy of Groundwork Wirral) .

7.4 Bidston Moss in 2001 (Photo courtesy of Groundwork Wirral)... .

7.5 Moston Vale before regeneration.

(Photo courtesy of Chris Robinson) . .

7.6 Moston Vale after regeneration (Photo courtesy of Chris Robinson).

7.7 Map of the site of the future National Forest, 1991 (Map courtesy of the National Forest Company) . . . . . . . . .

7.8 The National Forest in March 2007 (Map courtesy of the National Forest Company) . . . . . . . . . . . . . . . .

7.9 Beginning regeneration work at Bentley colliery (Yorkshire) (Photo courtesy of Chris Robinson) . . . . . . . . . .

7.10 Community woodland and semi-commercial plantations now cover the site at Bentley colliery (Photo courtesy

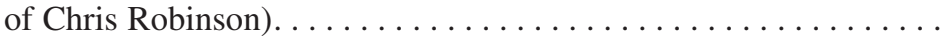

8.1 Flying 'carbon-neutral' from the Liverpool John Lennon airport (Photo Sylvie Nail) . . . . . . . . . . . . . . .

8.2 Good for biodiversity, bad for $\mathrm{CO}_{2}$ : the dilemma of dead wood (Photo courtesy of the Mersey Forest) . . . . . . . .

9.1 Cultivating health in Thrive gardens (Photo courtesy Thrive) .... .

9.2 Walking one's way to health in the new plantations of the Mersey Forest (Photo courtesy of the Mersey Forest) . . . . . .

9.3 Tree-planting as part of the REACT project in Liverpool (Photo courtesy of the Mersey Forest) . . . . . . . . . . . . . . .

9.4 Leaping over the fence: woodland at Prescot High School (Merseyside) (Photo Sylvie Nail) . . . . . . . . . . . . . . . 
9.5 Developing schoolgrounds to enrich the educational experience (Photo courtesy of the Mersey Forest) $\ldots \ldots \ldots \ldots \ldots \ldots \ldots$

9.6 Children are taught that woodland has to be managed (Photo courtesy of the Mersey Forest) $\ldots \ldots \ldots \ldots \ldots \ldots \ldots$

10.2 Green corridors between Telford New Town and the surrounding countryside (Photo courtesy of Alan Simson).

10.3 Visitors are made welcome on private property, here on agricultural land converted into woodland as part of the Mersey Forest (Photo Sylvie Nail) . . .

10.4 Simple boards at Risley Moss, headquarters of the Mersey Forest, help the visitor to find his/her way round and choose between various walks (Photo Sylvie Nail)

10.5 Stolen and burnt cars are among the most visible forms of vandalism in woodlands, as here in Mill Wood, an ancient wood straddling Speke, Halton and Knowsley (Merseyside) (Photo Sylvie Nail) ..................

11.1 Commercial outlets, a new kind of neighbourhood?

Cheshire Oaks, Chester (Cheshire) (Photo Sylvie Nail) . . . . . . . . .

11.2 Model resulting from a Planning for Real exercise in High Hazels, Sheffield (Photograph with kind permission of Planning for Real, a registered trademark of Neighbourhood Initiatives Foundation) $\ldots \ldots \ldots \ldots \ldots \ldots \ldots \ldots \ldots \ldots \ldots \ldots$

11.3 The UK has $30 \%$ of the world population of bluebells. Joining the Bluebell Express offers communities the chance to see them - and to reconnect with the local countryside (Photo courtesy

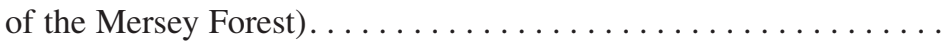

11.4 Planting trees during National Tree Week, a multi-purpose, inter-generational pursuit (Photo courtesy of the Mersey Forest $) \ldots \ldots \ldots \ldots \ldots \ldots \ldots \ldots \ldots$

11.5 A 'Vandal-proof' bench, also devised to evoke the area's past industrial activity. Freeman's Copse, Ellesmere Port (Photo Sylvie Nail) . . . . . . . . . . . . . .

11.6 Newly-planted trees may act as scapegoats to vent frustration and anger (Photo courtesy of the Mersey Forest) . . . . .

11.7 Rediscovering the woods and a sense of adventure high up in the trees (Photo Sylvie Nail) $\ldots \ldots \ldots \ldots \ldots \ldots$ 
12.1 Robin Hood takes on the Sheriff of Nottingham close to the Major Oak in Sherwood Forest during the Robin Hood Festival 2006 (Photo courtesy of the Nottingham

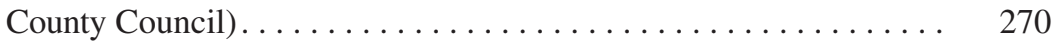

12.2 An old pollarded hornbeam in two halves in Hatfield Park (Photo courtesy of Mark Johnston) . .

12.3 'Horsepower' to remove logs from woodland (Photo Tree News, Spring-Summer 2007: 11, with kind permission of Daniel Butler).

12.4 Millenium Yews: a propagule of a yew tree taken in 1999 from a churchyard tree in Linton (Surrey) now grows in the Dartmoor churchyard of Buckland Filleigh (Photo courtesy of Fergus Kinmonth). .

12.5 The President of Interfaith, also Lord Mayor of Nottingham, plants trees as part of the Inter Faith project in Notthingham (Photo courtesy of the Inter Faith Council) . . . . .

12.6 Woodland burial ground in Frankby (Wirral). A few seasons on, the burial-ground will look like a woodland glade, with no apparent trace of the deceased (Photo Sylvie Nail). 


\section{List of Tables}

6.1 Why support forestry with public money (From Forestry

Commission. 2005a: 9)

6.2 Facilities and activities provided at Forestry Commission sites (Adapted from Forestry Facts and Figures 2001, 2002, 2003, 2004, 2005: table 11: Forest Enterprise recreation facilities and activities. Edinburgh: Forestry Commission). .

9.1 Table of published sources on environmental psychology in the United States

9.2 Table of published sources on environmental psychology in Britain.

11.1 Targets and number of events held in the Community Forests (From Evaluation of the Community Forest Programme. Final Report. 2005. Land use Consultants and SQW Ltd, table 6.1: Targets and numbers of events held, p. 71). .

11.2 Breakdown of events in the Community Forests for 2004-2005 (From Community Forests Monitoring Report 2004-2005. Final Report, Community Forest Partnership, 2005,

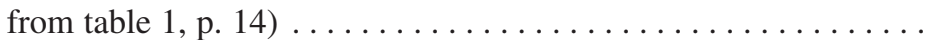




\section{Introduction}

Forests lie at the heart of intersecting topical issues at the beginning of the third millennium. With the advent of the post-industrial, post-productivist era in many countries of the Western world, the forestry sector has undergone dramatic changes. For instance in England, the price of timber decreased dramatically in the late 1990s, but indirect market benefits and non-market benefits, including recreation, health and regeneration, have grown. These now loom large in the equation of forest profitability.

One of these benefits relates to a wider international agenda, that of the preservation of biodiversity, which has important consequences in terms of management policies and practices. Traditional resource management has led to criticisms and to forestry practices being questioned over the last decades, while sustainable ecosystem-based forest management has developed. What Kennedy et al. describe as the transition from a machine model to an organic model, hinging on relationships [Kennedy et al. 1998], has led to another characteristic, the inclusion of the socio-cultural environment of forestry.

What follows from this is two-fold. First, forests are now perceived as cultural landscapes, that is to say intentional as well as unintentional expressions of history, environment and cultural identity combined. These social constructions reflect the values of society, understood as contingent concepts of worth informed by 'ethical and moral judgements' [O'Brien 2003: 5]. Conversely, forests feed societies' dreams, myths and memories. The second corollary is the widening of the forestry agenda to include such social issues as the fight against social deprivation and exclusion, especially in urban areas. Indeed, urbanisation has been a driving force, not only in Europe, but also in developing countries, as the subtitle of the UN World Environment Day 2005, held in San Francisco, emphasised: 'Green Cities: where the future lives'. Forestry in urban areas, a recent development as will be seen, has undoubtedly become a way of delivering sustainable development: international projects exemplify this strategic approach to urban forestry in Europe.

All in all, the stakes have become increasingly complex with the advent of multipurpose forestry.

These issues, together with the rise of new academic disciplines (environmental history, landscape ecology, cultural geography, environmental psychology, among them), have led to copious research in relation to wooded landscapes in many 
countries, focusing on history, politics, aesthetics, biodiversity, cultural meanings, recreational functions or economic value. More often than not, however, such aspects are dealt with in isolation, cut off from one another.

Similarly, urban and rural issues are often dealt with separately, which in many cases is no longer relevant. Forests, like any other landscape, are more than the sum of their parts, and their analysis must be based on both their material forms and on the economic and ideological context in which they were construed. Policies and perceptions are frequently dealt with in different books, written by specialists of different disciplines, and the connection between the two is lost. Yet, in order to understand the applications and implications of policies, it is imperative, not only to address economics, leisure, heritage and symbolism, but to address them jointly so as to see how they interact, in order to form a picture of the place forests occupy, physically and symbolically, today. Interactions are fundamental, and policies can fail if they do not take perceptions into account.

The main thrust of this book is thus to explore the multifarious uses, functions and values of forests, whether rural, peri-urban or urban, at the beginning of the 21 st century in England. This entails, first, analysing British governments' responses, ${ }^{1}$ in so far as values underlie public policies and determine to a certain extent the means deemed most appropriate to reach the public good. It also entails relating these courses of action to social change, that is, to the transformations in the functioning, structure and culture of society in England.

International agreements and European policies obviously frame British policies and influence perceptions to a certain extent. They are presented whenever relevant, as well as examples of initiatives in other countries. Yet, it is argued that England offers a particularly relevant illustration of the issues mentioned above, and of original policies implemented to respond to the new challenges of forestry today.

The definition of woodland in the UK is slightly different from that in other countries. It refers to land under stands of trees with a canopy cover of, or the potential to reach, at least $20 \%$, but with no minimum height to form a mature woodland, whereas the international definition is based on a $10 \%$ canopy cover and a minimum height of 5 metres at maturity. There is no precise definition of 'forest' in the UK, and no minimum size, either (although statistics sometimes make a distinction between woodlands of more than 2 hectares and those of less than 2 hectares). As will be shown, the term 'forest' has been used with different meanings over the centuries; today, it tends to be associated mostly, but not exclusively, with large planted areas. Forests and woodlands are part and parcel of the English culture and identity, strongly marked by class and power relationships throughout history. As such, they are invaluable elements of analysis of the English society. Furthermore, England is at the leading edge of urban and social forestry on the international scene.

\footnotetext{
${ }^{1}$ Until the devolution process of the late 1990s, which is explained in Chapter 3, the Forestry Commission operated at the level of Great Britain (i.e. England, Scotland and Wales), hence the need to analyse forest policies at the British level.
} 
In 2007, English woodlands covered 1.124 .000 hectares, that is to say $8.6 \%$ of the total land area, a smaller percentage of the land than in most other European countries [Forestry Commission 2007: table 1.2]. Yet, they have over the last 15 years become the objects of an amazing array of initiatives, programmes, grant schemes and, more than anything else, of copious discourse on their value and multiple benefits. This attention bears no relation to their modest contribution to the national economy, which raises the question of their real missions, material and symbolical. England therefore offers a privileged environment in which to observe how perceptions shape policies, and conversely how policies can modify perceptions, as well as how both are grafted onto to the national cultural heritage.

Public policies such as the England Forestry Strategy (1998) jointly address all the issues related to woodland. The purpose of this book is to deal jointly with all these topics, too, through a social sciences perspective, in order to assess public policies in relation to people's perceptions of woodlands, and to show, in a mirror effect, the place and value of woodland and what these reveal of the English society in the 21st century, of its problems, aspirations and vision of itself. It makes use of existing literature and of the numerous reports on multifarious aspects of English woodland. More than anything else, it is based on a close scrutiny of official publications and abundant fieldwork with numerous interviews.

Through this book, it is hoped to contribute to improving the knowledge of issues which may be peripheral to arboricultural and forestry practices, but are felt by professionals working in these fields, especially in urban forestry, to be lacking from their training. The readers may include specialists of public policies in relation to open spaces and (urban) forests, including those who devise and implement them (among them professionals of arboriculture), as well as social science researchers, human geographers and forest historians. The book is also intended as a resource to higher education, hoping that students of forestry/arboriculture, landscape architecture, ecology, environmental studies and urban/rural planning will find in it tools to reflect on practices. Because England is a leader in the field of urban and social forestry, this research may be of interest to academics and practitioners in other countries, too. The wide public of tree-lovers will hopefully find here fresh insight into the stakes behind tree policies.

The thematic organisation of the book reflects its wide-ranging scope.

The preliminary chapter is designed to provide the historical landmarks in the woodland history of England, i.e. the background necessary to understand the present situation. It constitutes the starting-point of the questioning on the roles and functions of today's woodland. It reviews the main characteristics of English woodland through time, so as to enhance the political, economic, social and cultural traits indispensable to an understanding and assessment of present trends: the natural data, the links of woodland with political power and the traditional economic and symbolical functions of woodland in pre-industrial England. Furthermore, it illustrates the two basic principles that underlie forestry throughout history: in order for woodlands to exist, there has to be no better use of the land, and forestry has to be profitable. This raises the question which informs the whole book: what is the rationale of woodland today? Do the old criteria still exist? If so, are they still valid, or are they present in a different form? 
The first part focuses on the institutionalisation of forestry since 1919, a turningpoint in the destiny of forests and woodlands through the creation of the Forestry Commission. A lot has been written on the first 50 years of the Forestry Commission, and this chapter avoids repeating previous publications on the subject. Rather, it wants to attract attention to some characteristics which were dogma for several decades, not only in Britain but also on the international scene, and have shaped today's forestry, for example in terms of landscapes and economics. The chapter then explores the changes in emphasis following the economic failure of British forestry and presents the contents and impacts of institutional changes, within the Forestry Commission and also in the UK at large, due to devolution at the end of the 20th century. It also presents the new focus of public policies through an analysis of the 1998 England Forestry Strategy.

The next chapter demonstrates how today's new forestry paradigm stems directly from two main influences: the failure of the productivist ethos and a change in perceptions and priorities on the international scene. One of the dominant features of the last three decades, in England as in many other countries, has been the rise of urban forestry, the definition, remit, tools and applications of which are discussed in the last chapter of this first part.

To a certain extent, the second and the third parts reflect the official classifications of woodland benefits: market benefits and non-market benefits. But the purpose goes beyond following this classification, which does not do justice to the width and breadth of woodland issues, in particular to the underlying values of woodlands or to the power of representations. Yet, the latter can promote or hinder public policies, especially in the case of non-market benefits. Typical examples of this phenomenon are presented in connection with programmes related to education, health, community participation and access, where values and perceptions, when they are ignored, can clearly stand in the way of public policies being effective. Furthermore, the advent of urban forestry, especially since the 1980s as far as England is concerned, has changed the agenda and put an end to traditional categories (rural/urban, market/non-market). Instead, two visions of woodland emerge which apply to both cities and the countryside.

The second part reviews the concept of multi-purpose forestry and its consequences on woodlands. Although financial returns are given a low priority today, the calculations made to assess the benefits of forestry nevertheless rely more often than not on financial valuation, which leads to a certain ambiguity. The first chapter of this part focuses on the direct market and non-market benefits, with new outlets and new emphases. Another aspect of multi-purpose forestry very much stressed in official literature is its role in rural and urban regeneration, which is the object of the next chapter. This particular area relates to the economy, in so far as there are obvious financial returns expected from regeneration (e.g. inward investment), but it also reflects changes in the economy that call for changes in land use. The discourse on regeneration is scrutinised, so as to elicit what missions forestry is supposed to fulfil, then compared with incentives and programmes, in particular in the 12 Community Forests, showing that action does not always match rhetoric or social needs. 
Arguably the first function of 21 st century forestry is linked to the environment, pollution and climate change in particular. This is what the following chapter focuses on, bearing in mind the context of the production of scientific knowledge, in order to review the recognised scientific facts, and expose the fantasies and the exploitation of the tree image to enlist support and generate profits. This chapter analyses these issues and shows that, all in all, the image of the tree is exploited beyond what can reasonably be expected of trees and woodlands. The latest agenda of forestry, i.e. social issues, is the object of the last chapter of this part. Health and education, which are part of this agenda, are presented together because they have a lot in common in terms of objectives and of strategies. As in the previous chapters of this part, it is shown here that economic benefits are not absent from the agenda (for example, in terms of savings in the health sector or better trained youths). Moreover, official programmes, as well as those implemented by charitable organisations, reveal new definitions of health and education and a new conception of the missions of the State in these areas, to which social forestry can contribute.

The third part of the study moves into the realm of perceptions and politics. It explores how policies may differ from people's expectations and what woodlands, old or new, mean to people. The first chapter revolves around the controversial issue of amenity and access. All the policies described in the previous chapters rely for their success on regular contact with woodland, yet this is far from being simple, with the structure of land ownership in England making access/ibility problematic. Moreover, the issue of access/ibility is a culturally rooted one and its treatment today is indicative of social relationships. The discourse on the benefits of urban and community forestry emphasises the importance of people's participation as part of sustainable community building. The next chapter thus explores the theoretical framework behind participation and how it is interpreted by the Community Forests teams. This is supported by fieldwork and other studies showing, first, that woodland represents a minority interest and, secondly, that there remain obstacles to social inclusion, let alone empowerment, in English society.

Last but not least, the final theme explored in this book focuses on questions of conservation and argues that behind what may appear as motivated solely by issues of biodiversity/landscape heritage, there lies in the woodland a wealth of representations and identity markers which contribute to forming and informing people's perceptions of woodlands in the 21 st century.

\section{References}

Forestry Commission. 2007. Forestry Statistics 2007. Woodland Areas and Planting. http://www. forestry.gov.uk/website/forstats2007.nsf/LUContents/4E46614169475C868025735 D00353CC8. Accessed 20 November 2007.

Kennedy, J., M. Dombeck and N. Koch. 1998. Values, beliefs and management of public forests in the Western world at the close of the twentieth century. Unasylva 49 (192): 16-26.

O'Brien, E. 2003. Human values and their importance to the development of forestry policy in Britain: a literature review. Forestry 76 (1): 3-17. 